\title{
Site preparation and competing vegetation control affect loblolly pine long-term productivity in the southern Piedmont/Upper Coastal Plain of the United States
}

\author{
Dehai ZhaO*, Michael Kane, Bruce E. Borders, Mike Harrison, John W. Rheney
}

Warnell School of Forestry and Natural Resources, University of Georgia, Athens, 30602 GA, USA

(Received 2 December 2008; accepted 14 May 2009)

Keywords:

intensive forest management /

fertilization /

herbicides /

growth and yield
Mots-clés :

gestion intensive des forêts /

fertilization /

herbicide /

croissance et productivité

\begin{abstract}
- A site preparation study was established in 1986 to evaluate the effect of different site preparation treatments on growth and yield of loblolly pine (Pinus taeda L.) plantations on the Piedmont and Upper Coastal Plain regions of the southern United States. Site preparation treatments included: (1) burn only, (2) chop-burn, (3) shear-pile-disk, (4) chop-herbicide-burn, (5) herbicide-burn, and (6) herbicide-burn-herbicide.

- The data from the available 19 installations at age 21 were analyzed with separate analysis of variance and a multilevel nonlinear mixed-effects modeling approach.

- The herbicide-burn-herbicide treatment significantly increased average Dbh, height, basal area and volume per hectare compared to all other treatments. The burn only treatment consistently ranked worst and was followed by the chop-burn treatment. The shear-pile-disk and chop-herbicide-burn treatments had similar overall growth pattern, and will approach the same level of pine volume as the herbicide-burn treatment.

- Loblolly pine mean annual increment in volume $\left(\mathrm{m}^{3} \mathrm{ha}^{-1} \mathrm{y}^{-1}\right)$ at age 21 by treatment were: herbicide-burn-herbicide (17.9), shear-pile-disk (16.1), herbicide-burn (15.9), chop-herbicide-burn (15.4), chop-burn (14.3), and burn (11.2).

- An additional chop or herbicide treatment to the burn treatment significantly increased loblolly pine yield. Complete control of both herbaceous and woody completion enhanced long-term pine productivity.
\end{abstract}

Résumé - La préparation du terrain et le contrôle de la végétation adventice affectent la productivité à long terme de Pinus taeda dans les stations des Piémonts du sud et des plaines côtières des États-Unis d'Amérique.

- Une expérimentation destine à tester la préparation du terrain a été installée en 1986 pour évaluer l'impact de différents traitements de préparation du terrain sur la croissance et la productivité de Pinus taeda L. dans les plaines du Sud des États-Unis d'Amérique. Les traitements comprenaient : (1) un brûlis, (2) un débroussaillage suivi de brûlis, (3) un andainage automatique, (4) un débroussaillage suivi d'un traitement herbicide et d'un brûlis, (5) un traitement herbicide suivi de brûlis, (6) un herbicide suivi d'un brûlis et d'un second traitement herbicide.

- Les données issues de 19 blocs ont été analysées après 21 ans de croissance, en utilisant des analyses de variance séparées ainsi qu'un modèle mixte non linéaire plusieurs niveaux.

- Le traitement herbicide-brûlis-herbicide a augmenté de manière significative le diamètre à $1 \mathrm{~m} 30$, la hauteur, la surface terrière et le volume sur pied par rapport à tous les autres traitements. Le brûlis seul a produit les résultats les plus médiocres, suivi par le débroussaillage-brûlis. Les traitements avec andainage et broyage et celui avec débroussaillage-herbicide-brûlis ont présenté des croissances comparables, and se rapprochent du traitement herbicide-brûlis.

- L'accroissement annuel moyen à 21 ans $\left(\mathrm{m}^{3} \mathrm{ha}^{-1} \mathrm{y}^{-1}\right)$ était de 17,9 (herbicide-brûlis-herbicide), 16,1 (débroussaillage-andainage-broyage), 15,9 (herbicide-brûlis), 15,4 (broyage-herbicide-brûlis), 14,3 (broyage-brûlis) et enfin 11,2 (brûlis seul).

- En conclusion, compléter le brûlis par un traitement herbicide ou un broyage des rémanents a permis d'augmenter de manière très significative le rendement de Pinus taerda. Un contrôle précis de la competition par les herbacées et les plantes ligneuses a permis d'augmenter la productivité de Pinus taeda sur le long terme.

\footnotetext{
*Corresponding author: dzhao@ warnell.uga.edu
} 


\section{INTRODUCTION}

The successful establishment and subsequent growth of loblolly pine plantations begins with site preparation. Site preparation treatments are designed to reduce competing vegetation, dispose of logging debris, improve soil conditions, and facilitate planting (Godefroid et al., 2007; Morris and Lowery, 1988; Shiver and Martin, 2002). Several significant classes of site preparation for regenerating southern pines in the United States are prescribed burning, mechanical, and chemical site preparation. Prescribed burning is often a relatively low cost method of preparing planting sites. However, prescribing burning by itself is not a dependable method of competition control or debris reduction on many sites. On many tracts, site preparation burns may not be an option due to site or liability considerations. When it is an option, prescribed burning can be used in combination with many chemical and mechanical treatments. Mechanical site preparation methods were commonly used from the late 1950s through the mid 1980s and before the availability of effective and environmentally friendly herbicides. Most mechanical methods such as chopping, shearing, disking, and bedding are directed toward the removal of competing vegetation and producing a site suitable for planting. Mechanical site preparation can improve tree growth by increasing the availability of water and nutrients to the planted seedlings and improving planting quality (Allen and Lein, 1998; Morris and Lowery, 1988). Mechanical site preparation often is relatively costly, a concern for forest managers (Morris and Lowery, 1988; Piatek and Allen, 2000). Application of chemical herbicides is an alternative or complement to mechanical site preparation for meeting objectives of control of competing vegetation. Herbicide can be used to effectively control competing vegetation with little soil disturbance. Because of advantages in costs and effectiveness in competition control as compared to mechanical methods, the use of herbicides for site preparation in southern pine forests has become increasingly popular since the 1980s.

Loblolly pine (Pinus taeda L.) growth is adversely affected by both herbaceous and woody competition; compared to herbaceous cover, shrub cover can be a greater competitor and resulted in greater reduction of pine growth over the long term (Lauer and Glover, 1998, 1999; Lauer and Zutter, 2001; Zhao et al., 2008; Zutter and Miller, 1998). Different methods of site preparation treatments result in various levels of efficacy in controlling competing vegetation (Lauer and Quicke, 2006; Lauer and Zutter, 2001; Shiver and Martin, 2002), and thus result in different pine growth responses in terms of type and magnitude (Lauer et al., 1998; Morris and Lowery, 1988; Nilsson and Allen; 2003; South and Miller, 2007). Lauer et al. (1998) found that on upland sites mechanical site preparation resulted in more woody competing vegetation than chemical site preparation, while mechanical treatment resulted in less herbaceous vegetation than chemical site preparation. Chemical site preparation combined with early herbaceous weed control improved seedling establishment and early growth (Lauer et al., 1998), and more intensive site preparation which reduced competition from hardwoods might improve a longterm stand volume growth (Nilsson and Allen, 2003).
To effectively control competing vegetation and improve soil conditions for planting and pine growth, forest managers frequently apply combinations of site preparation treatments (Lauer et al., 1998; Nilsson and Allen, 2003; Zhao et al., 2008). The use of herbicides in combination with mechanical treatments may provide better control of both herbaceous and woody vegetation, thus increasing pine growth and production and shortening rotation length (Lauer and Quicke 2006; Lauer and Zutter, 2001; Zhao et al.; 2008; Zutter and Miller, 1998), and increasing financial return for forest landowners and managers. Site preparation effects on early loblolly pine growth are relatively well documented in the literature. However, few studies have examined the effect of site preparation on the long-term production in detail.

In 1986, the Plantation Management Research Cooperative (PMRC) at the University of Georgia established a study to evaluate the effects of six different site preparation methods on the growth and yield of loblolly pine plantations in the Piedmont/Upper Coastal Plain of the southern US. Shiver and Martin (2002) reported on twelve-year results from this study, using analyses of variance (ANOVA) to examine treatment differences at a specific age. The present study emphasized the differences in overall growth response patterns among different site preparation treatments, with separate ANOVA analysis at several ages and a multilevel nonlinear mixed-effects modeling approach. The objectives were (1) to evaluate the long-term effects of site preparation treatments and sustained competition control on loblolly pine growth and yield, (2) to examine the differences in growth response patterns among the site preparation and vegetation control treatments, and (3) to provide useful information for modifying site preparation and complete control approaches for managing loblolly pine in the southern United States.

\section{MATERIALS AND METHODS}

\subsection{Study description}

The loblolly pine site preparation study was installed at 25 locations throughout the Piedmont and Upper Coastal Plain of South Carolina, Georgia and Alabama in the United States. The existing stand at each location was harvested in 1984 and planting completed during the 1985-1986 planting season. Sites were selected to ensure reasonable uniformity in site quality and competing vegetation characteristics across the study area. Each installation consisted of seven square 0.5 acre treatment plots with an interior square 0.2 acre measurement plot. The following site preparation treatments were randomly assigned to the treatment plots at each location: (1) Burn only, 2) chop-burn, (3) shear-pile-disk, (4) chop-herbicideburn, (5) herbicide-burn, and (6) herbicide-burn-herbicide. Each installation also contained a replicate of one treatment randomly selected from all treatments excluding the burn only treatment. Detailed information concerning the treatments and this designed study can be found in Shiver and Martin (2002).

The plots were hand-planted with first-generation, improved planting stock during the winter of 1985-1986 at a $2.4 \mathrm{~m}$ by $3.0 \mathrm{~m}$ spacing. Two seedlings were planted at each planting spot 
and, if both survived after the first growing season, one was eliminated. This resulted in reasonably uniform stocking of approximately 1347 trees ha $^{-1}$ across all installations. All plots were fertilized at age 13. The fertilization treatment was carried out using $140 \mathrm{~kg} \mathrm{ha}^{-1}$ of diammonium phosphate (DAP) and $432 \mathrm{~kg} \mathrm{ha}^{-1}$ of Urea, equivalent to $224 \mathrm{~kg} \mathrm{ha}^{-1}$ of $\mathrm{N}$ and $28 \mathrm{~kg} \mathrm{ha}^{-1}$ of $\mathrm{P}$.

After the third growing season, tree heights were measured and crown class was recorded. From ages 6 to 21 y, triennial measurements of diameter at breast height (Dbh) for all trees and height for every other tree were collected from each measurement plot. Heights of the unmeasured trees were estimated using a height-diameter equation, $\ln (H)=\alpha+\beta D^{-1}$ ( $H$ is tree height and $D$ is tree $\left.\mathrm{Dbh}\right)$, fitted to each plot at each measurement age. Total outside bark volumes were estimated using total volume equation developed by Pienaar et al. (1987).

The amount and composition of hardwood and herbaceous competition on the site preparation plots were monitored through age 18 with nine, $1.22-\mathrm{m}$ radius subplots on each measurement plot. The measurements on each subplot fall into three categories: herbaceous, small hardwood (stems with Dbh less than $10.2 \mathrm{~cm}$ ) and large hardwood (hardwood stems with Dbh greater than $10.2 \mathrm{~cm}$ ). Herbaceous competition was assessed on a subplot basis where the cover percent and average height of herbaceous vegetation types were measured for the subplot. For small hardwoods, species, height and crown length were measured and recorded on individual stems or rootstocks; the measurements of species, Dbh, height, bole height and crown width were taken on each large hardwood stem.

After 21 growing seasons 19 of the original 25 installations are viable. Six installations were lost to bark beetle or after they were thinned. Data from the 19 installations active at age 21 were used for the analysis reported here.

\subsection{Data analysis}

Installations were treated as random factors of the experiment since region-wide recommendations were the objectives of the study. The replication within an installation represented an attempt to quantify the within location error. Analysis of variance (ANOVA) with a mixed model approach was used to detect significant differences among site preparation treatments, because this approach allows for the mixed effects and unbalanced nature of this design. The installation and interaction of installation and treatment were treated as random effects, and site preparation treatment was treated as a fixed effect. The analyses were carried out on pine survival, average Dbh, average height, basal area and total volume per hectare at each measurement age. Fisher's LSD test was used for all pairwise comparisons of least-squares means to detect differences between site preparation treatments. All statistical tests were conducted at the $\alpha=0.05$ significance level. To obtain the correct degree of freedom the Satterthwaite option in SAS ${ }^{\circledR}$ 's PROC MIXED procedure was used (Littell et al., 2006).

Compared with the burn only treatment, the growth response due to other site preparation treatments were calculated as differences in least squares means. Response patterns over time were characterized by maximum response, age at time of maximum response, and response type. Response types were identified as: (1) response magnitude increase with time; (2) response peak is attained and maintained; (3) response peaks and diminishes somewhat with time.

In addition to performing separate ANOVA at each measurement age, due to the repeated measures and unbalanced natures of this experiment, a multilevel nonlinear mixed-effects modeling (MLNLMM) approach was applied to test site preparation treatment effects on volume growth patterns. A modified Chapman-Richards model (Ratkowsky, 1990) was used as the general volume growth model:

$$
V=\gamma_{0}\left(\frac{1-\exp \left(-\gamma_{1} \text { Age }\right)}{1-\exp \left(-\gamma_{1} \text { Age }_{0}\right)}\right)^{\gamma_{2}}
$$

where parameter $\gamma_{0}$ is expected volume at given reference age $\mathrm{Age}_{0}$ (here, Age $_{0}=25$ year), $\gamma_{1}$ and $\gamma_{2}$ are rate of growth and curve shape parameters, respectively.

Five indicator variables were used to identify the six levels of treatments:

$$
\begin{aligned}
T_{1} & = \begin{cases}1, \text { if chop-brun } \\
0, & \text { otherwise }\end{cases} \\
T_{2} & = \begin{cases}1, \text { if shear-pile-disk } \\
0, & \text { otherwise }\end{cases} \\
T_{3} & = \begin{cases}1, \text { if chop-herbicide-brun } \\
0, \text { otherwise }\end{cases} \\
T_{4} & = \begin{cases}1, \text { if herbicide-brun } \\
0, & \text { otherwise }\end{cases} \\
T_{5} & = \begin{cases}1, \text { if herbicide-brun-herbicide } \\
0, & \text { otherwise }\end{cases}
\end{aligned}
$$

The site preparation treatments were considered fixed effects and all three parameters were assumed to depend linearly on these indicator variables. The installation- and plot-level effects were treated as random and expressed as $b_{\mathrm{i}}$ and $b_{\mathrm{ij}}$, respectively. Initially, all three parameters are taken as mixed, with random installation- and plot-level intercepts. Let $V_{\mathrm{ijk}}$ denote the stand pine volume per hectare for the $j$ th plot of the $i$ th installation at the $k$ th measurement time, thus the general nonlinear mixed model has the form:

$$
V_{\mathrm{ijk}}=\gamma_{0 \mathrm{ij}}\left(\frac{\left.1-\exp -\gamma_{1 \mathrm{ij}} \mathrm{Age}\right)}{\left.1-\exp -\gamma_{1 \mathrm{ij}} \mathrm{Age}_{0}\right)}\right)^{\gamma_{2 \mathrm{ij}}}+\varepsilon_{\mathrm{ijk}}
$$

where

$$
\begin{aligned}
& \gamma_{0 \mathrm{ij}}=\beta_{0}+\beta_{01} T_{1}+\beta_{02} T_{2}+\beta_{03} T_{3}+\beta_{04} T_{4}+\beta_{05} T_{5}+b_{\mathrm{i}}^{(0)}+b_{\mathrm{ij}}^{(0)} \\
& \gamma_{1 \mathrm{ij}}=\beta_{1}+\beta_{11} T_{1}+\beta_{12} T_{2}+\beta_{13} T_{3}+\beta_{14} T_{4}+\beta_{15} T_{5}+b_{\mathrm{i}}^{(1)}+b_{\mathrm{ij}}^{(1)} \\
& \gamma_{2 \mathrm{ij}}=\beta_{2}+\beta_{21} T_{1}+\beta_{22} T_{2}+\beta_{23} T_{3}+\beta_{24} T_{4}+\beta_{25} T_{5}+b_{\mathrm{i}}^{(2)}+b_{\mathrm{ij}}^{(2)}
\end{aligned}
$$

and assumes

$$
\left(\begin{array}{l}
b_{\mathrm{i}}^{(0)} \\
b_{\mathrm{i}}^{(1)} \\
b_{\mathrm{i}}^{(2)}
\end{array}\right) \stackrel{\text { i.i.d. }}{\sim} N\left(0, \Psi_{1}\right), \quad\left(\begin{array}{l}
b_{\mathrm{ij}}^{(0)} \\
b_{\mathrm{ij}}^{(1)} \\
b_{\mathrm{ij}}^{(2)}
\end{array}\right) \stackrel{\text { i.i.d. }}{\sim} N\left(0, \Psi_{2}\right), \quad \varepsilon_{\mathrm{ijk}} \stackrel{i . i . d .}{\sim} N\left(0, \sigma^{2} \Lambda_{\mathrm{ij}}\right) .
$$

The installation- and plot-level random effects, $\left\{b_{\mathrm{i}}\right\}$ and $\left\{b_{\mathrm{ij}}\right\}$, are assumed to be independent of each other.

Three phases of the model-building process are followed in the MLNLMM approach (Zhao et al., 2005). In the random-effects specification phase, significant random-effects terms and their corresponding appropriate variance-covariance matrices $\Psi_{1}$ and $\Psi_{2}$ are identified. Then, during the within-plot variance-covariance structure specification phase, the $\Lambda_{\mathrm{ij}}$ matrix is decomposed into a variance structure component and a correlation structure component, and these two components are specified. Finally, based on the nature of 
Table I. Least square means for loblolly pine average Dbh, average height, basal area, and total volume by site preparation treatment and age.

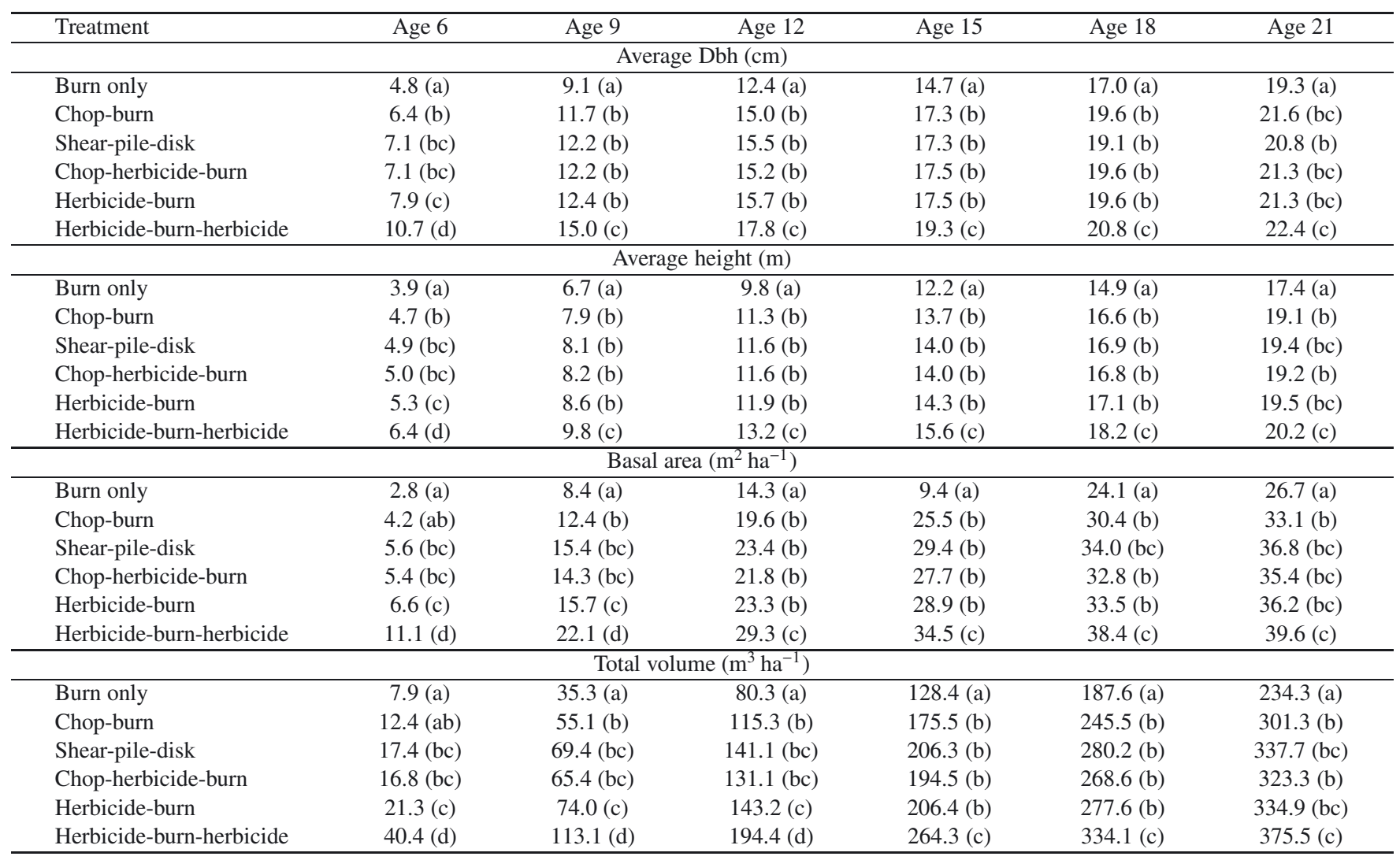

For a given age, different letters indicate significant differences in terms of the specific variable between site preparation treatments.

random-effects and variance-covariance given in the first two phases, the treatment effects are tested in detail via the likelihood ratio test (LRT) for fixed-effect parameter significance. In each step, different models are evaluated using LRT if the alternative models are nested, or the Akaike information criterion (AIC) or the Bayesian information criterion (BIC) if not nested. All the models can be fit using the NLME library of S-Plus (Pinheiro and Bates, 2000). For details of this three-phase modeling approach for modeling response curves and testing treatment effects in repeated measures experiments, we refer the reader to Zhao et al. (2005).

Competing hardwood vegetation was assessed with the variable defined as hardwood basal area as a proportion of total pine and hardwood basal area. This variable is useful for modeling pine basal area development, as recently shown by Borders et al. (2004a).

\section{RESULTS}

All resulting $p$-values from the test of site preparation treatment with ANOVA are less than 0.0001, indicating that site preparation treatments significantly affected survival, average Dbh, average height, basal area and total volume per hectare through age $21 \mathrm{y}$. Loblolly pine survival trends over time by site preparation treatment are shown in Figure 1; least squares means and mean separation for average Dbh and height, and basal area and total volume per hectare by treatment and measurement age are presented in Table I.

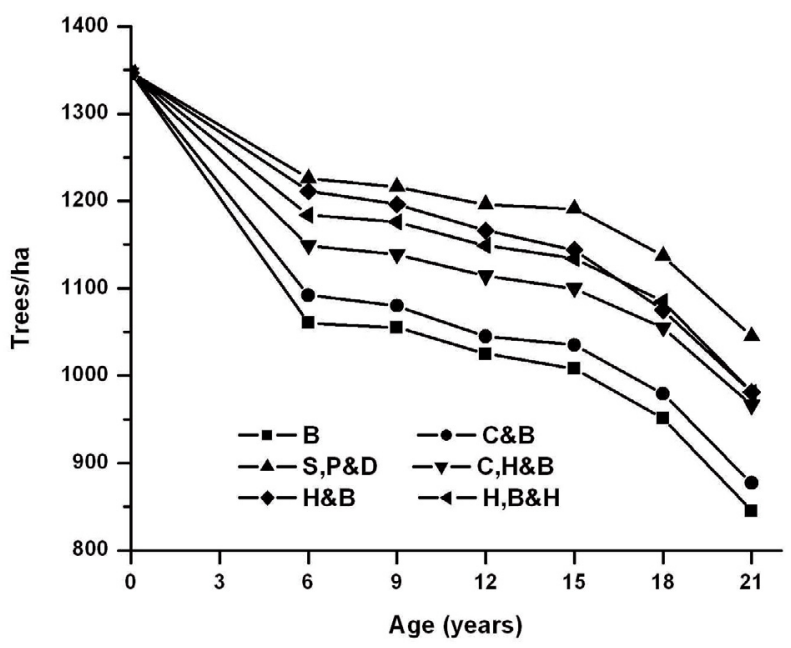

Figure 1. Loblolly pine survival trends over time by site preparation treatment: the burn only (B), chop-burn (C\&B), shear-pile-disk (S, $\mathrm{P} \& D)$, chop-herbicide-burn $(\mathrm{C}, \mathrm{H} \& \mathrm{~B})$, herbicide-burn $(\mathrm{H} \& \mathrm{~B})$, and herbicide-burn-herbicide $(\mathrm{H}, \mathrm{B} \& \mathrm{H})$ treatments.

In terms of survival, the burn only treatment and chop-burn treatment were not significantly different through age 21 y. A significant survival difference due to an herbicide application 

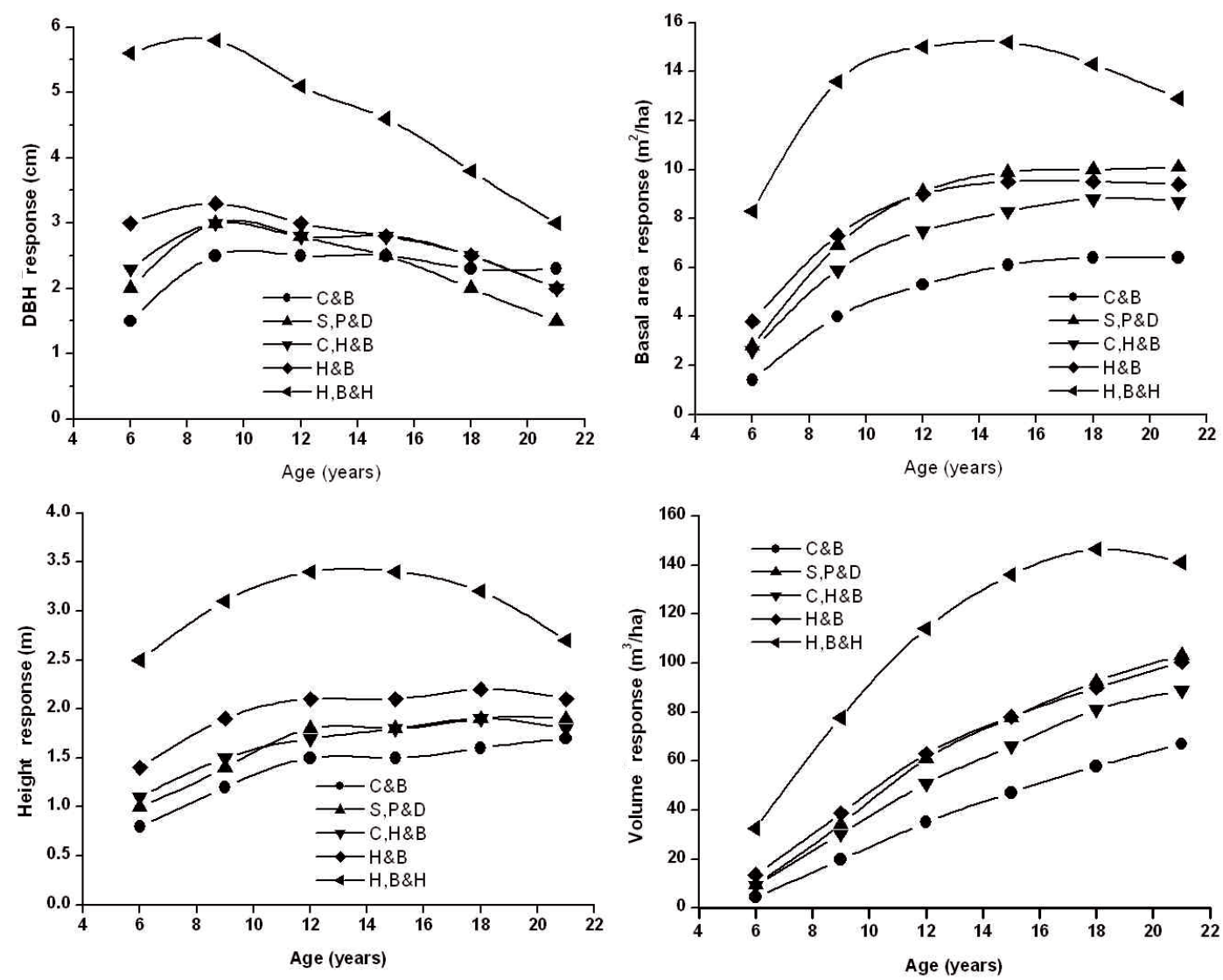

Figure 2. Loblolly pine average Dbh, average height, basal area and total volume responses as measured by the difference between the burn only treatment and chop-burn (C\&B), shear-pile-disk (S, P\&D), chop-herbicide-burn (C, H\&B), herbicide-burn (H\&B), or herbicide-burn-herbicide $(\mathrm{H}, \mathrm{B} \& \mathrm{H})$ treatments.

over the burn only treatment still existed after 21 growing seasons. The burn only treatment and chop-burn treatment had significantly lower survival than all other treatment which was not significantly different from one another (Fig. 1).

The burn only treatment had significantly lower average Dbh, average height, basal area and volume per hectare than all other treatments at each measurement age, with the exception of having no significant difference from the chopburn treatment for basal area and volume per hectare at age 6 (Tab. I). The herbicide-burn-herbicide treatment had significantly greater average Dbh, height, basal area and volume than all other treatments through age 18 . At age 21, the herbicideburn-herbicide treatment still had the greatest values for tree and stand level attributes but had no significant differences from some other treatments such as the herbicide-burn treatment and the shear-pile-disk treatment. No significant differences were detected between the chop-burn treatment, the shear-pile-disk treatment, the chop-herbicide-burn treatment, and the herbicide-burn treatment, after age 6 for average Dbh and height, after age 9 for basal area per hectare, and after age 12 for total volume per hectare.

Compared with the burn only treatment, responses of average Dbh, average height, basal area and total volume per hectare due to other site preparation treatments are shown in Figure 2. The herbicide-burn-herbicide treatment significantly improved Dbh, height, basal area and volume growth and the gains from this treatment were significantly and consistently greater than that from other treatments. The Dbh responses reached their maximum values ranging among treatments $2.5-5.8 \mathrm{~cm}$ at age 9 , and then diminished with time for all but the chop-burn treatment where maximum response was maintained. Height responses increased through age $21 \mathrm{y}$ for the chop-burn treatment; reached maximum responses of 1.9-2.2 $\mathrm{m}$ at age 18 for the shear-pile-disk, chop-herbicideburn, and herbicide-burn treatments; and peaked at age 12 with $3.4 \mathrm{~m}$ for the herbicide-burn-herbicide treatment. The basal area responses kept increasing through age 21 for the chopburn and shear-pile-disk treatments; peaked and maintained maximum response of 8.8 and $9.5 \mathrm{~m}^{2} \mathrm{ha}^{-1}$ at ages 18 and 15 for the chop-herbicide-burn and herbicide-burn treatments, respectively; and reached the maximum value of $15.2 \mathrm{~m}^{2} \mathrm{ha}^{-1}$ at age 15 and thereafter diminished somewhat with time for the herbicide-burn-herbicide treatment. Compared with the burn only treatment, the volume responses kept increasing through age 21 for the chop-burn, shear-pile-disk, and chop-herbicideburn treatments; and achieved its maximum of $146.5 \mathrm{~m}^{3} \mathrm{ha}^{-1}$ at age 18 that was maintained through age 21 for the herbicideburn-herbicide treatment. 
The effect of site preparation treatment on pine volume growth pattern was tested using the MLNLMM approach. In the random-effects specification phase, several models with all fixed effects terms but with different random-effects terms and a diagonal or general symmetric positive-definite variancecovariance matrix of the random effects were evaluated using the LRT $(p<0.01)$ or AIC (the smaller the better). It was found that all parameters $\gamma_{0}, \gamma_{1}$ and $\gamma_{2}$ should be taken as mixed effects, among which parameters $\gamma_{0}$ and $\gamma_{1}$ include all installation- and plot-level random effects, and parameter $\gamma_{2}$ includes only installation-level random effects. A general symmetric positive-definite matrix is preferred for both installation- and plot-level random effects. Even with random effects in the parameters, heteroscedasticity still exists in the mixed effects volume model. In the within-plot variancecovariance structure specification phase, it was concluded that an exponential of the fitted value variance function is preferable over a power of the fitted value variance function. A moving average MA(2) with the smallest value of AIC is the best autocorrelation structure, when compared with $\operatorname{AR}(1), \operatorname{AR}(2)$ and ARMA $(1,1)$. In the final model, therefore, the installationlevel random-effects were included in parameters $\gamma_{0}, \gamma_{1}$ and $\gamma_{2}$ and were correlated with each other; the plot-level randomeffects were included in parameters $\gamma_{0}$ and $\gamma_{1}$ and were correlated; an exponential function and $\mathrm{MA}(2)$ were selected to model the variance and the within-plot correlation structure, respectively.

Based on the nature of random-effects and variancecovariance structures, the significance of treatment effects was first assessed in terms of parameters $\gamma_{0}, \gamma_{1}$ and $\gamma_{2}$. Both the LRT for $\beta_{01}=\beta_{02}=\beta_{03}=\beta_{04}=\beta_{05}=0$ and $\beta_{21}=\beta_{22}=$ $\beta_{23}=\beta_{24}=\beta_{25}=0$ resulted in $p<0.0001$, indicating that the asymptote and shape parameters $\left(\gamma_{0}\right.$ and $\left.\gamma_{2}\right)$ of the volumeage curves were affected by site preparation treatment. The LRT for the null hypothesis $\beta_{11}=\beta_{12}=\beta_{13}=\beta_{14}=\beta_{15}=0$ suggested site preparation treatments did not change the rate parameter $\gamma_{1}(p=0.437)$. The LRT for $\beta_{02}=\beta_{03}=\beta_{04}$ and $\beta_{21}=\beta_{22}=\beta_{23}$ resulted in $p=0.605$ and $p=0.442$, respectively, suggesting the shear-pile-disk, chop-herbicideburn, and herbicide-burn treatments have the same effect in terms of the parameter $\gamma_{0}$, and the chop-burn, shear-pile-disk, and chop-herbicide-burn treatments have the same effect in terms of the parameter $\gamma_{2}$. All other hypotheses about fixedeffects term were rejected. Thus, we obtained the following reduced model:

$$
\hat{V}_{\mathrm{ijk}}=\hat{\gamma}_{0 \mathrm{ij}}\left(\frac{1-\exp \left(-\hat{\gamma}_{1 \mathrm{ij}} \mathrm{Age}\right)}{1-\exp \left(-25 \hat{\gamma}_{1 \mathrm{ij}}\right)}\right)^{\hat{\gamma}_{2 \mathrm{ij}}}
$$

where

$$
\begin{aligned}
\hat{\gamma}_{0 \mathrm{ij}}= & 276.5426+84.6238 T_{1}+101.4795\left(T_{2}+T_{3}+T_{4}\right) \\
& +151.751 T_{5}+b_{\mathrm{i}}^{(0)}+b_{\mathrm{ij}}^{(0)} \\
\hat{\gamma}_{1 \mathrm{ij}}= & 0.1328+b_{\mathrm{i}}^{(1)}+b_{\mathrm{ij}}^{(1)} \\
\hat{\gamma}_{2 \mathrm{ij}}= & 6.6389-0.9179\left(T_{1}+T_{2}+T_{3}\right)-1.492 T_{4} \\
& -2.3543 T_{5}+b_{\mathrm{i}}^{(2)} .
\end{aligned}
$$

Table II. Maximum likelihood estimates of the parameters (fixedeffects components) and their standard errors (SE) and $p$-values for the final mixed-effects loblolly pine volume model.

\begin{tabular}{lccc}
\hline Parameter & Estimate & SE & $p$-value \\
\hline$\beta_{0}$ & 276.5426 & 18.1975 & $<0.0001$ \\
$\beta_{01}$ & 84.6238 & 16.3823 & $<0.0001$ \\
$\beta_{02}=\beta_{03}=\beta_{04}$ & 101.4795 & 13.3223 & $<0.0001$ \\
$\beta_{05}$ & 151.7510 & 16.6878 & $<0.0001$ \\
$\beta_{1}$ & 0.1328 & 0.0060 & $<0.0001$ \\
$\beta_{2}$ & 6.6389 & 0.2480 & $<0.0001$ \\
$\beta_{21}=\beta_{22}=\beta_{23}$ & -0.9179 & 0.1977 & $<0.0001$ \\
$\beta_{24}$ & -1.4920 & 0.2103 & $<0.0001$ \\
$\beta_{25}$ & -2.3543 & 0.2063 & $<0.0001$ \\
\hline
\end{tabular}

Estimates of variance components corresponding to randomeffects of installations $\left[b_{\mathrm{i}}^{(0)}, b_{\mathrm{i}}^{(1)}, b_{\mathrm{i}}^{(2)}\right]^{T}$ and $\left[b_{\mathrm{ij}}^{(0)}, b_{\mathrm{ij}}^{(1)}\right]^{T}$ plots are

$$
\hat{\Psi}_{1}=\left(\begin{array}{ccc}
3335.64 & 0.1061 & 11.796 \\
0.1061 & 0.0006 & 0.0083 \\
11.7926 & 0.0083 & 0.2933
\end{array}\right), \hat{\Psi}_{2}=\left(\begin{array}{cc}
2028.86 & 0.2493 \\
0.2493 & 0.0002
\end{array}\right) .
$$

Estimates of parameters $\theta_{1}$ and $\theta_{2}$ for within-plot autocorrelation $\operatorname{MA}(2) \delta$, for exponential variance function, and $\sigma$ for residual errors are $\hat{\theta}_{1}=-0.02945, \hat{\theta}_{2}=-0.52787, \hat{\delta}=$ 0.00661 and $\hat{\sigma}=2.0338$, respectively. Other parameter estimates corresponding to fixed-effects and their asymptotic standard errors and $p$-values are summarized in Table II. With the final mixed-effects model, the standardized residuals plot does not reveal any observable pattern.

The typical pine volume growth curve across the study area for each site preparation treatment was obtained by setting all random effects to zero (Fig. 3). The shear-pile-disk and chopherbicide-burn treatments have the same overall growth pattern, with the same parameters $\hat{\gamma}_{0}=378.0221, \hat{\gamma}_{1}=0.1328$ and $\hat{\gamma}_{2}=5.7210$. The significant effect difference between the herbicide-burn treatment and the shear-pile-disk or chopherbicide-burn treatment was found only in terms of the shape parameter $\left(\hat{\gamma}_{2}=5.1469\right)$. The herbicide-burn-herbicide treatment results in the highest pine growth response, while pine volume with the burn only treatment is far less than all other treatments. In the absence of thinning, the shear-pile-disk, chop-herbicide-burn, and herbicide-burn treatments will approach the same level of pine volume per hectare, but still yield more pine volume than the chop-burn treatment.

The proportion of hardwood basal area at each measurement age by site preparation treatment is shown in Figure 4 . The percent hardwood basal area for the burn only treatment was $64 \%$ at age six; declined and stabilized at $35 \%$ by age 12 . For the chop-burn treatment, percent hardwood basal area was $25 \%$ at age six and declined to about $10 \%$ by age 15 . For the herbicide-burn, chop-herbicide-burn and shear-pile-disk treatments, percent hardwood basal area was approximately $15 \%$ at age six and declined to just over $5 \%$ by age 15 . The herbicideburn-herbicide treatment resulted in the complete vegetation control having no hardwoods through the study period. 


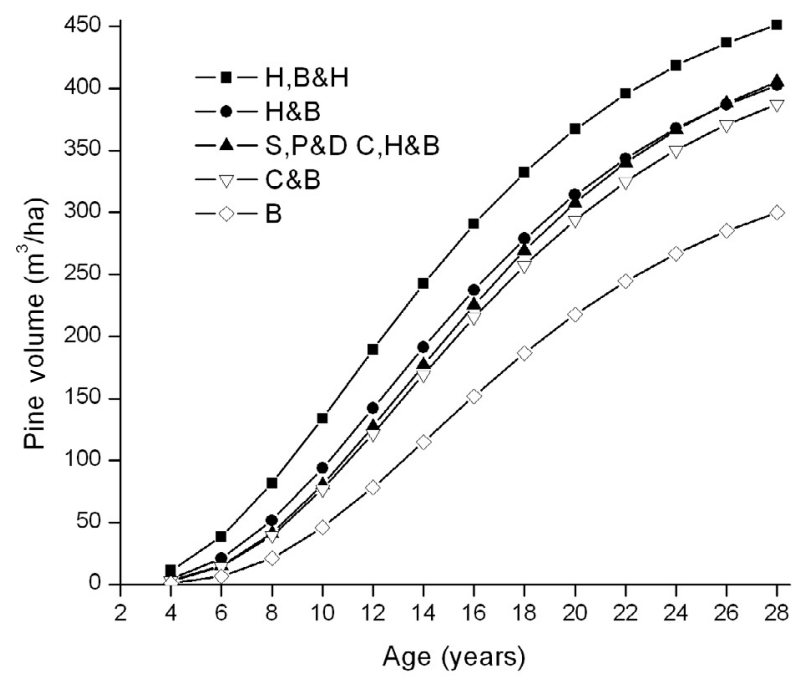

Figure 3. Comparison of predicted total loblolly pine volume growth by the burn only (B), chop-burn (C\&B), shear-pile-disk ( , $\mathrm{P} \& \mathrm{D})$, chop-herbicide-burn $(\mathrm{C}, \mathrm{H} \& \mathrm{~B})$, herbicide-burn $(\mathrm{H} \& \mathrm{~B})$, and herbicide-burn-herbicide $(\mathrm{H}, \mathrm{B} \& \mathrm{H})$ treatments with the multilevel nonlinear mixed-effects stand volume growth model, where all random effects were set to zero (using parameter estimates from Tab. II).

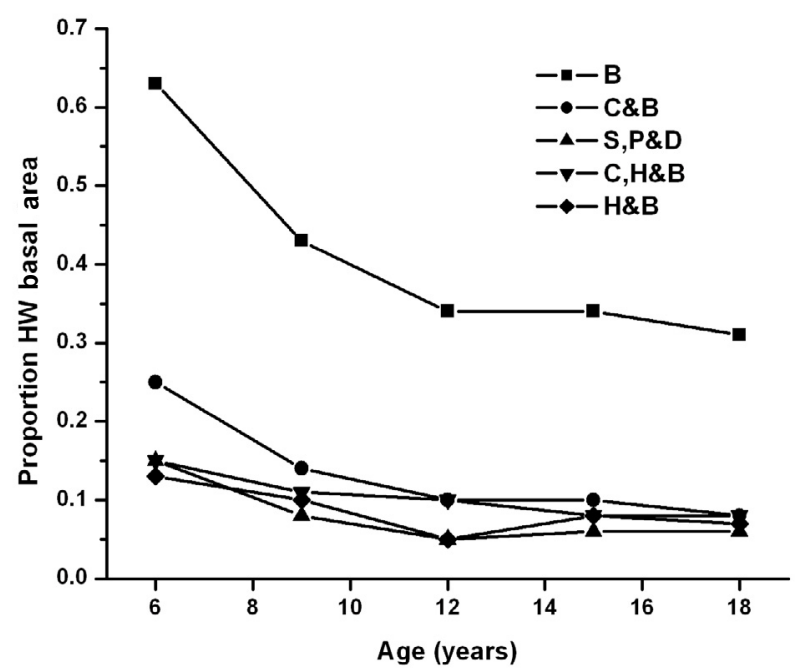

Figure 4. Hardwood basal area as a proportion of total stand basal area by age and site preparation treatment: The burn only (B), chop-burn (C\&B), shear-pile-disk (S, P\&D), chop-herbicide-burn $(\mathrm{C}$, $\mathrm{H} \& \mathrm{~B})$, and herbicide-burn $(\mathrm{H} \& \mathrm{~B})$ treatments. The herbicide-burnherbicide treatment resulted in no hardwoods over the study period.

\section{DISCUSSION AND CONCLUSIONS}

Separate ANOVAs indicate that site preparation treatment significantly affected loblolly pine average Dbh and height and per hectare basal area and volume at all measured ages. Site preparation treatment also altered overall volume per hectare by age pattern, as indicated by the MLNLMM approach results. The addition of either a chop or an herbicide treatment to the burn only treatment resulted in significant pine growth im- provement. This is because the intensive mechanical treatment (shear-pile-disk) or additional chop or herbicide treatment to the burn treatment improved hardwood control (Fig. 4). This improvement of hardwood control enhanced the long term productivity of loblolly pine plantations; a similar finding has been reported by Nilsson and Allen (2003).

The herbicide-burn-herbicide significantly increased loblolly pine yield through age $21 \mathrm{y}$ and will continue to yield more volume than other treatments. This treatment resulted in complete control of both herbaceous and woody competition and enabled the pine to grow free from interspecific competition (Shiver and Martin, 2002). Previous studies showed that control of both herbaceous and woody plants results in dramatic early pine growth (Lauer and Glover, 1998, 1999; Zhao et al., 2008; Zutter and Miller, 1998) and long-term pine growth response (Borders et al., 2004b; Nilsson and Allen 2003).

The addition of complete vegetation control to the herbicide-burn treatment resulted in significantly increased average Dbh, average height, basal area and volume per hectare. Herbaceous weed control often resulted in larger early growth gains than woody control and long term response to woody control was often greater than response to herbaceous weed control, as Miller et al. (2003) pointed out. After crown closure, herbaceous weed density declined from shade, resulting in a diminishing effect of herbaceous competition on pine survival and growth; while the difference in percent hardwood basal area between the herbicide-burn and complete control treatments played an important role in pine growth. More early growth gains due to the improved herbaceous control plus greater long-term growth response to the improved woody control resulted in the significant pine growth difference between these two treatments.

The shear-pile-disk treatment resulted in similar growth pattern as the chop-herbicide-burn treatment, due to their similar effectiveness in controlling competing hardwood vegetation over the life of study (Borders, 2004). It is noteworthy that there was no significant difference in competing hardwood control between the herbicide-burn treatment and the chopherbicide-burn treatment and they will approach the same level of pine volume.

Compared with the burn only treatment, the most intensive treatment (herbicide-burn-herbicide) reached the maximum pine volume response at age 18 and thereafter the growth was slowing down. This contrasts with greater pine growth on other site preparation treatments during the age 18 to $21 \mathrm{y}$ period. The shear-pile-disk, chop-herbicide-burn, and herbicideburn treatments provided sufficient survival and hardwood control that standing pine volume will be similar given a sufficiently long rotation. The burn only treatment had significantly lower pine survival (Zhao et al., 2007) and significantly greater hardwood stocking (Borders, 2004) to the point that the carrying capacity was shared between pine and hardwood components, thus resulting in its asymptotic pine volume far less than other treatments. The herbicide-burn-herbicide treatment eliminated all herbaceous and woody competition, thus resulting in the highest asymptotic pine volume. 
As the associate editor pointed out, the hardwoods are both a treatment response and a long-term factor in pine and total stand growth. In this study, we emphasized the effects of site preparation and competing vegetation control on long-term pine productivity. The hardwoods were quantified as a proportion of total stand basal area, rather than volume or biomass. It is clear that as the pines take the site from the hardwood at or shortly after crown closure the proportion of hardwood basal area diminishes quickly and then stabilizes (Fig. 4). Hardwood basal areas $\left(\mathrm{m}^{2} \mathrm{ha}^{-1}\right)$ at age 18 by treatments were: burn only (10.8), chop-burn (2.6), shear-pile-disk (2.2), chop-herbicideburn (2.9), herbicide-burn (2.5), and herbicide-burn-herbicide (0); resulting in total stand basal area of 34.9, 33.0, 36.2, 35.7, 36.0 , and $38.4 \mathrm{~m}^{2} \mathrm{ha}^{-1}$, respectively. Obviously, the effect of site preparation treatments on total stand basal area was not as strong as on pine stand basal area. Therefore, the hypothesis that the site preparation treatments did not affect the carrying capacity in terms of total stand volume or biomass is well worth testing.

These long-term results are unique in that they provide loblolly pine plantation responses over a 21 -year period to a variety of site preparation treatments observed on a large number (19) of test installations established on cut-over sites in the Upper Coastal Plain and Piedmont of Alabama, Georgia and South Carolina of the US South. Because of the regional nature of the research, the results provide reasonable estimates of responses expected to different types of site preparation on similar cut-over sites within this region. The treatments tested provide a range in intensity of site preparation and, in large measure, are directed at controlling competing vegetation. With the exception of the herbicide-burn-herbicide treatment, all practices associated with the tested treatments were implemented prior to planting. The complete and sustained nature of competition control associated with the herbicide-burnherbicide treatment allowed assessment of pine plantation productivity in the absence of interspecific competition.

Other regional trials examining long-term pine loblolly pine plantation productivity do not address the range of site preparation treatments examined in the study reported here but examine impacts of selected similar treatments, different aspects of site preparation, or different silvicultural manipulations such as fertilization.

Results from other loblolly pine productivity research with similar treatments are consistent with those found in this study. Increased pine productivity with more intensive site preparation treatments through age 18 on a series of six trials in the Lower and Upper Coastal Plains was attributed largely to more effective hardwood control (Nilsson and Allen, 2003). Similarly, pine productivity through age 20 on a site in the Georgia Piedmont was greatest with a shear, root rake, burn and disk treatment, intermediate for a shear and chop treatment and least for a chainsaw removal of residuals greater than 1 inch Dbh treatment (Edwards et al., 2004). The large productivity responses from complete and sustained control of both herbaceous and woody competitors are consistent with those reported for similar treatments through age 15 on a south-wide but predominantly Upper Coastal Plain and Piedmont study on competing vegetation impacts on pine productivity (Miller et al., 2003), through ages 10 to 11 for a study on complete competition control and annual fertilization impacts on multiple sites in the Piedmont and Upper Coastal Plain of Georgia (Borders and Bailey, 2001), and through age 10 on installations of a long-term soil productivity study in the West Gulf Coastal Plain (Scott et al., 2007).

The stand development and response patterns observed in this study occurred on sites that did not receive tillage with the exception of disking on the shear-pile-disk treatment and stands that received fertilization with the equivalent of $224 \mathrm{~kg} \mathrm{ha}^{-1}$ of $\mathrm{N}$ and $28 \mathrm{kgha}^{-1}$ of $\mathrm{P}$ at age 13 . In general, loblolly pine tillage responses on typical upland sites in the Upper Coastal Plain and Piedmont are relatively small compared to those obtained from other silvicultural practices such as vegetation control and fertilization (Carlson et al., 2006). Loblolly pine plantation productivity at and after crown closure is often limited by deficiencies in $\mathrm{N}$ and to a lesser extent $\mathrm{P}$ (Fox et al., 2007). The fertilization with $\mathrm{N}$ and $\mathrm{P}$ at age 13 was expected to provide adequate nutrition for good growth through at least age 20.

Forest managers with the objective of financial returns from pine timber management should evaluate tools available for effectively controlling both herbaceous weeds at plantation establishment and woody competitors. The herbicide choices have significantly improved since the time this study was installed, increasing land managers' opportunities for biologically and economically effective vegetation management. Mechanical site preparation treatments aimed at competition control, while potentially effective, are often typically more expensive, less effective, and more difficult to implement than chemical options.

Acknowledgements: We would like to express our gratitude to The University of Georgia's Warnell School of Forestry and Natural Resources and the Plantation Management Research Cooperative (PMRC) for providing support and data for this research. We are grateful the anonymous reviewers and the Associate Editor for their helpful comments for the manuscript.

\section{REFERENCES}

Allen H.L. and Lein S., 1998. Effects of site preparation, early fertilization, and weed control on 14-year old loblolly pine. Proc. South. Weed Sci. Soc. 51: 104-110.

Borders B.E., 2004. Piedmont and upper coastal plain loblolly pine site preparation study: Results through age 18. PMRC technical report 2004-3, University of Georgia, Athens, GA, 29 p.

Borders B.E. and Bailey R.L., 2001. Loblolly pine - pushing the limits of growth. South. J. Appl. For. 25: 69-74.

Borders B.E., Harrison W.M, Zhang Y., Shiver B.D., Clutter M., Cieszewski C., and Daniels, R.F., 2004a. Growth and yield models for second rotation Loblolly pine plantations in the Piedmont/upper coastal plain and lower coastal plain of the southeastern U.S. PMRC technical report 2004-4, University of Georgia, Athens, GA, 67 p.

Borders B.E., Will R.E., Markewitz D., Clark A., Hendrick R., Teskey R.O., and Zhang Y., 2004b. Effect of complete competition control and annual fertilization on stem growth and canopy relations for a chronosequence of loblolly pine plantations in the lower coastal plain of Georgia. For. Ecol. Manage. 192: 21-37. 
Carlson C.A., Fox T.R., Colbert S.R., Kelting D.L., Allen H.L., and Albaugh T.J., 2006. Growth and survival of Pinus taeda in response to surface and subsurface tillage in the southeastern United States. For. Ecol. Manage. 234: 209-217.

Edward M.B., Shiver B.D., and Logan S.R., 2004. Effects of five silvicultural treatments on loblolly pine in the Georgia Piedmont at age 20. South. J. Appl. For. 28: 35-40.

Fox T.R., Allen H.L., Albaugh T.J., Rubilar R., and Carlson, C.A., 2007. Tree nutrition and forest fertilization of pine plantations in the southern United States. South. J. Appl. For. 31: 5-11.

Godefroid S., Monbaliu D., Massant W., Van Der Aa B., De Vos B. Quivy V., and Koedam N., 2007 Effects of soil mechanical treatments combined with bramble and bracken control on the restoration of degraded understory in an ancien beech forest Ann. for. Sci. 64: 321-331.

Lauer D.K. and Glover G.R., 1998. Early pine response to control of herbaceous and shrub vegetation in the flatwoods. South. J. Appl. For. 22: 201-208.

Lauer D.K. and Glover G.R., 1999. Stand level pine response to occupancy of woody shrub and herbaceous vegetation. Can. J. For. Res. 29: 979-984.

Lauer D.K., Muir R.L., and Glover G.R., 1998. Combining herbicide applications with mechanical site preparation. Proc. South. Weed Sci. Soc. 51: 112-113.

Lauer D.K. and Quicke H.E., 2006. Timing of chopper herbicide site preparation on bedded sites. South. J. Appl. For. 30: 92-101.

Lauer D.K. and Zutter B.R., 2001. Vegetation cover response and secondyear loblolly and slash pine response following bedding and pre- and post-plant herbicide applications in Florida. South. J. Appl. For. 25: $75-83$.

Littell R.C., Milliken G.A., Stroup W.W., Wolfinger R.D., and Schabenberger O., 2006. SAS ${ }^{\circledR}$ for mixed models, 2nd ed. SAS institute Inc. Cary, NC, 814 p.

Miller J.H., Zutter B.R., Zedaker S.M., Edwards M.B., and Newbold R.A., 2003. Growth and yield relative to competition for loblolly pine plantations to midrotation - A southeastern United States regional study. South. J. Appl. For. 27: 237-252.

Morris L.A. and Lowery R.F., 1988. Influences of site preparation on soil conditions affecting stand establishment and tree growth. South. J. Appl. For. 12: 170-178.
Nilsson U. and Allen H.L., 2003. Short- and long-term effects of site preparation, fertilization and vegetation control on growth and stand development of planted loblolly pine. For. Ecol. Manage. 175: 367-377.

Piatek K.B. and Allen H.L., 2000. Site preparation effects on foliar N and $\mathrm{P}$ use, retranslocation, and transfer to litter in 15-years old Pinus taeda. For. Ecol. Manage. 129: 143-152.

Pienaar L.V., Burgan T., and Rheney J.W., 1987. Stem volume, taper and weight equations for site-prepared loblolly pine plantations. University of Georgia, school of forest resources PMRC research paper 1987-1, Athens, GA, 11 p.

Pinheiro J.C. and Bates D.M., 2000. Mixed-effects models in S and S-PLUS, Springer-Verlag, New York, 528 p.

Ratkowsky D.A., 1990. Handbook of nonlinear regression models, New York, Marcel Dekker, 241 p.

Scott A.D., Novosad J., and Goldsmith G., 2007. Ten-year results from the North American long-term soil productivity study in the western gulf coastal plain. Advancing the fundamental sciences: proceedings of the forest service national earth sciences conference, pp. 331-340.

Shiver B.D. and Martin, S.W., 2002. Twelve-year results of a loblolly pine site preparation study in the Piedmont and Upper Coastal Plain of South Carolina, Georgia, and Alabama. South. J. Appl. For. 26: $32-36$.

South D.B. and Miller J.H., 2007. Growth response analysis after early control of woody competition for 14 loblolly pine plantations in the southern U.S. For. Ecol. Manage. 242: 569-577.

Zutter B.R. and Miller J.H., 1998. Eleventh-year response of loblolly pine and competing vegetation to woody and herbaceous plant control on a Georgia flatwoods site. South. J. Appl. For. 22: 88-95.

Zhao D., Kane M., Borders B.E., and Harrison M., 2007. Piedmont and upper coastal plain loblolly pine site preparation study: results through age 21. PMRC technical report 2007-4, University of Georgia, Athens, GA, 50 p.

Zhao D., Kane M., Borders B.E., and Harrison M., 2008. Pine growth response to different site-preparation methods with or without postplant herbaceous weed control on north florida's lower coastal plain. For. Ecol. Manage. 255: 2512-2523.

Zhao D., Wilson M., and Borders B.E., 2005. Modeling response curves and testing treatment effects in repeated measures experiments: a multilevel nonlinear mixed-effects model approach. Can. J. For. Res. 35: 122-132. 